\title{
Investigating Effective Factors on Development of Iran's Caviar Exports
}

\author{
Zare Zardeini Hosein ${ }^{1}$, Seyyed Mohammad Tabatabaei Mehrizi ${ }^{2} \&$ Ahmad Yousefie Hanoomarvar $^{3}$ \\ ${ }^{1}$ Department of Management, Ferdowsi University of Mashhad, Mashhad, Iran \\ ${ }^{2}$ Science and Research Branch, Islamic Azad University, Tehran, Iran \\ ${ }^{3}$ Department of Management, Allameh Tabataba'i University, Tehran, Iran \\ Correspondence: Zare Zardeini Hosein, Department of Management, School of Administrative \& Economic \\ Science, Ferdowsi University of Mashhad, Mashhad, Iran. E-mail: Hzare622@gmail.com
}

Received: December 27, 2012

Accepted: January 11, 2013

Online Published: January 25, 2013

doi:10.5539/ibr.v6n3p117

URL: http://dx.doi.org/10.5539/ibr.v6n3p117

\begin{abstract}
The purpose of this paper is to explore effective factors on development of Iran's caviar exports. The survey information is collected from books and journals. Assumptions checked base on data collected from a questionnaire. Data is analyzed with SPSS software and One-sample t-test method. Sample consists of 50 experts and exporters of caviar that chooses with random sampling. we find that familiarity of the Exporters with exports principles, Introducing nutritive and treatment value of caviar to the goal markets, foreign investment absorption, Proper processing and high quality of caviar, Diversification in the packaging capacity of caviar based on consumer's purchasing power and Having good political relations with other countries increase export caviar but Producing farmed caviar by other country decrease Iran's caviar exports. This paper will provide important factors that will essentially help to develop export of Iran's caviar and create a good condition for this industry.
\end{abstract}

Keywords: caviar, Sturgeon, processing caviar, competitiveness, exports

\section{Introduction}

Economic development is one of the important goals of each society in the world and economic growth is one of the basic factors in order to gain this goal. Many factors cause economic growth but in economic studies export are the most efficient tool to achieve economic growth (Francis et al., 2007). Researchers and the diplomats of Iran found out the importance of exports as an important and efficient strategy for economic development. In this regard, the government's economic reform programs are developed and implemented. Iran's Economic sensitivity to changes in oil world markets and fragility in the face of foreign pressure has led to consider diversification in exports by the government and emphasize on Non-oil export development strategy. In Iran Non-oil, products are produce in a variety of goods including agricultural, Industrial products, minerals and handicrafts (Mojaver, 2009). Among of non-oil Products, agriculture goods is a significant factor in economic development and growth. Dependence of agriculture production to the internal sources such as human and natural sources makes agriculture sector more important. Agricultural products of Iran are exporter in a variety of goods including nuts, raisins, saffron, dates, cotton, skins and caviar (Dashti et al., 2010). Caviar as a luxury and expensive commodity has an important place in the export products of Iran and has high economic value. Having 2700 kilometers sea border in the north and south of the country and wide facilities and resources, are the advantages of Iran in producing caviar. Appropriate depth and good temperature of the Caspian Sea are causes growing the best caviar fishes at the south of Caspian Sea and its coast.

Investigating the trend of Iran's caviar production and its exports show decreasing exports of this product in recent years, But Iran's experience in the production of caviar, Iranian caviar quality and high prices in global markets has caused adding value of this export product. Therefore, investigate effective factors on development of Iran's caviar exports are necessary and can improve its position in the export sector. However, unfortunately up to now, no operational research has been taken in this regard and lack of information has been felt in this area. This study will attempt to identify and analysis these factors and finally presents strategies for increasing the exports of this product. 


\section{Caviar and Its Value in Nutritive and Treatment}

Caviar is sturgeon eggs that are not fertilized. Caviar is a delicious breakfast and is used separately or mixed with other foods. Most of people eat it with egg yolk or small onions, and others eat it with the aromatic vegetables with small pieces of bread and butter. Root of Caviar word is Persian and means ovipositor. Caviar word is common English and Persian. In Russia, the products obtained from fish eggs are called Ikra and Ikura, is the Japanese term used for caviar. Fishing and processing caviar in Iran has a long history, so that Ancient Persians in $3000 \mathrm{BC}$ was familiar with the nutritional value of caviar and they processed and used it (Sternin \& Dore, 1993).

Caviar is a nutritious food and Full of useful materials for growth and human health. Caviar consumption can recover the person lost energy in major surgery and infectious diseases (Sternin \& Dore, 1993). Caviar consumption can also reduce the effects of anesthesia of surgery and is useful in the treatment of rickets (Bledsoe et al., 2003). Natural Caviar has 16 to 39 percent protein (Murad \& Rasco, 2005). These are high quality and variety of proteins including 73 types of proteins such as phenylalanine, valine, tryptophan, methionine, leucine, lysine, and threonine. These proteins are essential and the human body cannot manufacture them (Keyvanshokooh \& Vaziri, 2008). Caviar is rich in vitamins A, D, $B_{1}, B_{2}, B_{12}, C, E$ and consumption of it facilitates Metabolism and helps to produce amino acids, fats and carbohydrates and facilitates Growth and recovery of body's cells (Bledsoe et al., 2003). Caviar also has essential minerals for body such as iron, phosphorus, potassium, sulfur, calcium, magnesium, zinc, Manganese, lead, cadmium and copper (Wang et al., 2008).

Another useful compound of the caviar is unsaturated fat. Unlike Saturated fats, consumption of unsaturated fat is useful for the body and is necessary for body growth and health. Lack of unsaturated fat in the body can cause serious complications such as skin, gastrointestinal, neurological disorders and brain dysfunction. The highest amounts of caviar unsaturated fats makes up omega-3. This combination is essential for the functioning of the body and prevents the increase of blood cholesterol and cardiovascular disease. Omega-3 also increases calcium absorption and facilitates Calcium Sediment in bone tissue and As a result, helps prevent osteoporosis. This material is effective in the treatment of depression, dry eye, obstructing blood vessels and reduces the incidence of breast, ovarian, prostate and gastrointestinal cancers (Badiani, 2002).

However, due to decreased production of natural caviar, farmed caviar consumption has increased but this kind of caviar has less nutritional value. Research has shown that the amount of protein, calories and fatty acids in farmed caviars are less (Gessner et al., 2002). Moreover, extract of caviar from Sturgeon requires them to reach maturity, which includes long time (12-8 years); also the high cost of farmed these fishes, has led to use regular fish eggs such as salmon fish and lumpfish to produce farmed caviar by producing countries. Using these kinds of fishes reduces produced caviar quality. Also due to the use of chemical colors and flavors in producing this type of caviar its consumption is harmful to the body (Sternin \& Dore, 1993).

\section{Sturgeons}

One of the most valuable aquatic species is caviar fishes. This fishes that are called fish Dice and fish cartilaginous are from fish family of Sturgeons, which their Origin and background refers back to about 150 million years ago. Until the past few centuries, sturgeon were scattered around of the world but nowadays, their generation has decreased and its fishing and processing has been limited to the Caspian Sea (Pikitch et al., 2005). Among the 27 species of sturgeon, five major species live in the Caspian Sea included: Huso hus fish, Acipenser Gueldenstaedtii percicus, Acipenser Gueldenstaedtii Colchicus, Acipenser Nudiventris fish and Acipense rstellatus fish the extracted caviar of these fishes is original caviar and Among these, Beluga caviar which extracted from Huso Hus fish has the best quality and the highest price (Altuga \& Bayrakb, 2003).

\subsection{Huso Hus Fish}

Russian name of this fish is Beluga But due to its large size and face similarity to the elephant this fish is known as elephant fish in Iran. This fish is the only carnivorous fish in its group and is the biggest fish in the Caspian Sea, which has the best quality of caviar extract. The fish stature is about a half feet to over four meters and weigh of typical size of these fish is between 40 to $300 \mathrm{~kg}$ but some samples with $1400 \mathrm{~kg}$ weight and age of 100 years were caught. This species spawning time is once in every two or three years and adult age is between 16 and 18. Number of Huso hus fish egg varies depending on the size of fish and normally are between 150000 to 2500000. The fish eggs have a diameter between 3.6 to $4 \mathrm{~mm}$ and are the world's most expensive caviar (Aghbaie \& Falahati, 2008). 


\subsection{Acipenser Gueldenstaedtii Percicus}

Another name for this species is ghar- boroon and this Turkish name means the black nose. This species is also known as the Iranian sturgeon. Acipenser percicus fish is bigger than Acipenser gueldenstaedtii fish. Its darker color and White spots on its back differentiate it from Acipenser gueldenstaedtii fish. Extracted caviar from Acipenser percicus fish has lower quality than Huso hus fish. Acipenser percicus fish weight is about $60-130 \mathrm{~kg}$. Its normal length is $1 \mathrm{~m}$ but observed over $2 \mathrm{~m}$. spawning time of this fish is in ages of 12 to 14 . The number of fish eggs is between 70 to 800 thousand eggs and their size is between 1.5 to $3 \mathrm{~mm}$. Eggs of this fish have golden brown color (Kohneshari \& Nakami, 1996).

\subsection{Acipenser Gueldenstaedtii Colchicus}

Chalbash is another name of this fish. It is among the species that found throughout the Caspian Sea. Extracted Caviar from this fish is also called a Golden and is ranked third in terms of value. Its adult age is between 12 to 16 years. The numbers of its eggs are between 70 to 800 thousand eggs, which sizes are between $1 / 5$ to $3 \mathrm{~mm}$. These fishes length are 1 to 2 meters and their weigh are 60 to $100 \mathrm{~kg}$ (Eshternin \& Doreh, 1993).

\subsection{Acipenser Nudiventris Fish}

This fish also called Ship fish. Usually these fishes are migratory fish that they come to Iran beaches due to spawn. They spawn in the catchment area of rivers of the Caspian Sea. Ship fish lifetime is equivalent to 30 years. Its adult age is between 10 to 14 years. Number of Acipenser Nudiventris fish eggs is between 200,000 to 1.3 million and its diameter is between 1.5 to $1.75 \mathrm{~mm}$. Extracted caviar of this fish doesn't have high quality and is ranked fourth in terms of value (Eshternin \& Doreh, 1993).

\subsection{Acipense Stellatus Fish}

This fish also called Sevruga. Extracted Caviar of this fish is the smallest and darkest one. Some experts believe that it is the most delicious caviar. Length of this fish is between 1 to 1.5 meters and its weight is lighter than other fishes. This Fish becomes maturity in age of 8 to 12 and its number of eggs is between 20 to 362 thousand units. This fish's eggs are tiny, and between 1.2 to $2.5 \mathrm{~mm}$ in diameter and have a dark gray color (Vosoghi \& Behzadi, 1995).

Naturally, sturgeon fishes spawn once a year after reaching maturity. By increasing lifetime, the gap between periods of their spawning is increasing too. They lose their spawning and Fertility potential at old ages. In fact, one of the reasons of caviar scarcity and Exclusive is late puberty and long period between spawning and maturity (Bledsoe et al., 2003).

\section{Processing of Caviar}

Processing of caviar is the scientific technique that needs high creativity and skill. There are a variety of materials and different caviar processing ways to produce high quality and Market friendly products. Different methods of processing refer to different caviar processing techniques such as salting, temperature, humidity of Caviar and concentration of salt solution (Gessner et al., 2002).

Processing of Caviar begins with fishing and extracting eggs from fish abdomen. To consider on maturation of fish and ovarian maturation is important in fishing. Fishing immature fish and using immature eggs in caviar production leads to reduce quality and quantity of caviar production. In the past, extracting eggs from fishes were led fish to die. But today by using Caesarean method we can avoid it. In this method, eggs are extracted from fishes by doing surgery and fishes are thrown back to the sea when the recovery is complete. After extraction, the eggs are screened to remove scar tissue. Using good tools and experts in ovary screening will reduce eggs injuries and damages. Salting is next step in this process, which is too important. Salting effects on amount of slimy of internal egg liquid. This slimy is one of the most important superior indicators of Caviar quality. Salting method, salt Purity, and amount of used salt are factors, which determine slimy of caviar. Using Gross salt at this stage can cause the growth of fungi and other microorganisms that are resistant to salt in the caviar. The amount of salt used in caviar determine by maturation of eggs and period of salting. After salting, the excess moisture of eggs is gotten and the final product will be ready for packaging. Caviar's Moisture level is the determining factor in quality of the caviar. Getting excessive moisture causes drying of the caviar and sticking eggs to each other. High Moisture also causes accumulation of Latex at the bottom of the container and reducing Persistence of caviar (Johannesson, 2006).

Packaging is one of the important factors of producing food. Appropriate packaging will facilitate marketing and increase sales of caviar. Consideration to the target market in caviar packaging and the package shape and size will help to increase sales of caviar (Aghdaie, 2009). Now Iranian caviar is packaging in containers of 100, 200, 
$300,600,1800$ gram. High price of caviar and high capacity of these packages causes price increasing and decreasing of sales. So considering low capacity packages and low sales price can increase caviar consuming between low-income people and increasing sales.

\section{Exports}

Export is the simplest and most common method for creating and developing foreign markets which Based on production volume and export policies, are done by one of two direct and indirect methods. In indirect methods, export is done without participation of producers and developing export companies of origin countries. The direct method is to sell the product directly to the importer or buyers in the foreign market and transactions are done by distributors and dependent agencies of the company (Kantapipat, 2009). Although indirect method is less costly and less risky but failure to control the market by producer causes fundamental problems such as sold through inappropriate sales channels and inadequate advertisements. Compared with the indirect method, direct export is more costly and risky but Due to the elimination of intermediates is more Profitable (Aghdaie, 2009).

Export trend in last century shows change position of Iran between caviar exporters. In the first half of the twentieth century due to lack of refrigerated transport industry, Iran could not export caviar and Iranian caviar was widely purchased and exported by the Soviet Union. The state of being fished and processed in the midtwentieth century, and development of transportation industry and cooling industry, in these years Iran could obtain ability to export high quality caviar and entered to the world market As the second largest exporter of caviar after Russia (Eshternin \& Doreh, 1993). After the Soviet collapse in 1990, Russia, Kazakhstan, Turkmenistan and Azerbaijan entered to the caviar export market and became known as the largest exporter of caviar after Iran. Nowadays Iran, Russia and Kazakhstan dominate on world caviar market, and Iran is known as the biggest exporter of natural caviar (Pikitch et al., 2005).

According to statistics data, the amount of caviar trade between 1998 and 2004 was about 1,324 tons, in which Iran with 465 tons, Russia with 138 tons, Kazakhstan with 95 tons and Azerbaijan to export 35 tons was known as the largest exporters of natural caviar. Versus Europe Union, the United States and Switzerland's was the largest caviar importers in the past year and $81 \%$ of the natural world's caviar is exported to these countries. Among the EU countries, Germany and France are allocated the highest volume of imported caviar and most of their imports were from Russia and Iran (www.traffic.org).

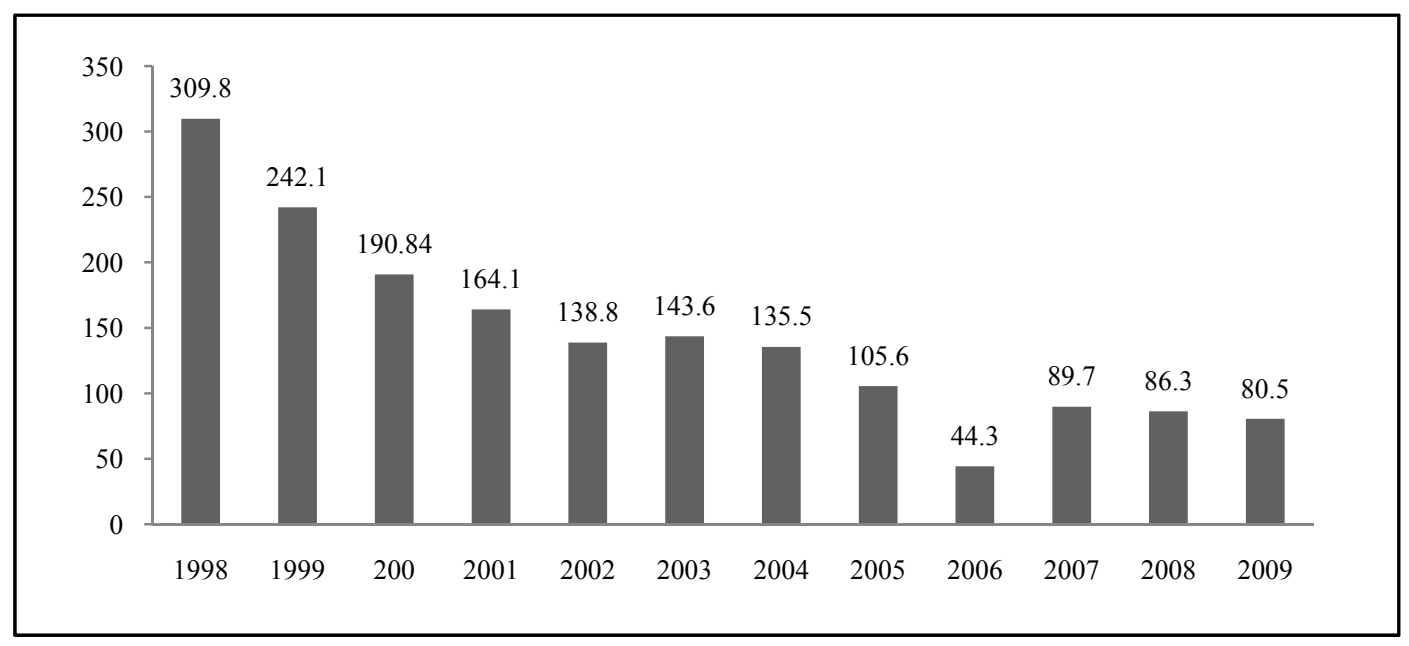

Figure 1. caviar's words export from 1998-2009

Source: www.cites.org.

By reducing Sturgeon, the rate of natural caviar trade is declined at international level. Amount of caviar production between 1998 and 2009 was 1730 tons that reached from 309.8 tons in 1998 to 80.5 tons in 2009 (Figure 1). Investigating export of caviar in recent years reflects unpleasant condition of this industry and reducing of caviar export. As shown in Figure 2, Iranian caviar exports decrease from 110 tons in 1998 to 1.8 tons in 2009. Germany, France, Italy, Japan, UAE, Luxembourg, Spain and Belgium are major importers. Among these countries Germany has been the largest importer of Iranian caviar in the past few years. The export method to these countries is through an auction (www.cites.org). 


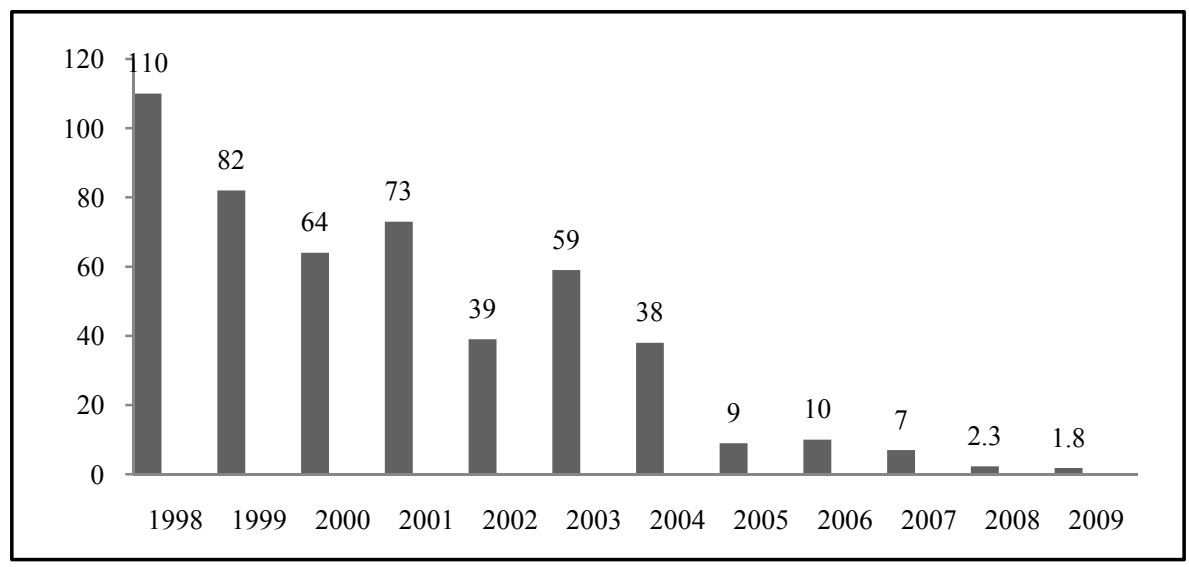

Figure 2. Iran's caviar export from 1998-2009

Source: www.cites.org.

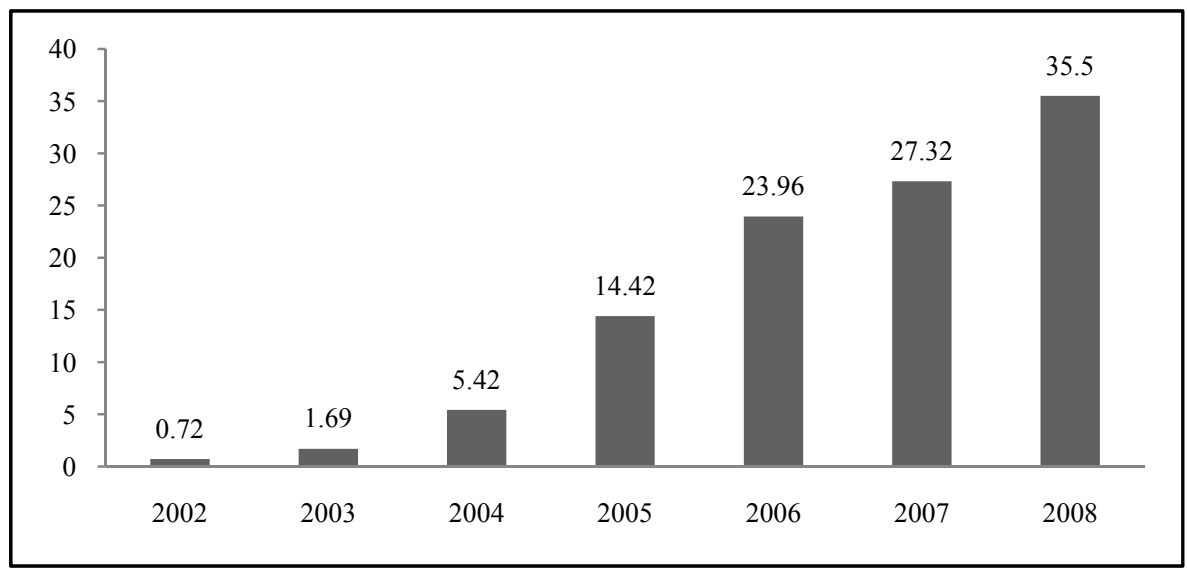

Figure 3. Farmed caviar's words export from 1998-2008

Source: www.cites.org.

The main reason of reducing the natural caviar export is decline of the Caspian sturgeon population. Overfishing, destruction of rivers, entering the municipal wastewater and agricultural pesticides to the Caspian Sea and increasing industrial pollution are the factors that have caused this decline. Therefore, in order to preserve the sturgeon population, CITES secretariat determines new laws regarding the quotas export of caviar and sturgeon fishing every year, and communicated to the Persian Gulf states (Raymakers, 2002). Refers to the popularity and quality of Iranian caviar and positive actions taken by Iran In the field of conservation and restoration of sturgeon stocks, Iran is allocated the largest export quota in the past few years to itself, so that, In 2006, the Secretariat has set export quotas only for Iran (www.cites.org).

Reducing of natural caviar exports, increasing demands for caviar and increasing caviar price create Suitable condition for production and export of farmed caviar. The first step in the production and export of this caviar has been taken by Russia and Germany (Williota et al., 2001). Nowadays, Germany, Russia, America, Italy, France and China produce farmed caviar for trade (Bledsoe et al., 2003). Statistics data also showed an increased export of farmed caviar in international markets that the production of 0.72 tons in 2002 reached to 35.5 tons in 2008 (Fig. 3).

\section{Competitiveness}

Common mean of competitiveness is ability to produce products with high competitive power in international markets (Cho et al., 2008). Traditional trade theorists believe that competitiveness of countries is for gaining appropriate capital, labor and natural resource. According to theory of absolute advantage of Adam Smith, countries export products that it can produce with less cost. David Ricardo believed that countries allocate their resources to the industries which have higher productivity in compared with other industries (Porter, 1990). Michael Porter's in 1990 published his book with title of "The Competitive Advantage of Nations" and 
presented his Diamond of competitive advantage model. In this model, unlike traditional approaches, a set of conditions and factors affecting the competitiveness is considered. This model has two variables, internal and external variables. Internal variables include corporate strategy and structure, related and supporting industries, production conditions and demand conditions while external variables are government and chance (Cho et al., 2008).

Despite the comprehensiveness of porter's diamond model, this model has been criticized and reviewed by researchers. One of these reviews is the Double Diamond model (Rugman,1991), Contrary to Porter's diamond model, which focuses only on the domestic environment; Double diamond model includes international issues and is applicable in the global market (Rugman \& D'Cruz, 1993), Another review of porter's model is nine factor model presented by Cho and Moon in 2000. They considered four other human variables in addition to Porter include: workers, policy makers, entrepreneurs and professionals, Although Porter's diamond model consider human variables; nine factor models also separates the physical variables from human factors and provides a clearer view of competitiveness. Government in Porter's diamond model is considered as an external variable While in the nine factors model as an internal variable that can affect the international competitiveness of industries.

Iran's caviar industry is an industry with a long history of export -oriented. The industry with the potential capacity of 500 tons of caviar in year has, the largest, most modern and most extensive network of production and supply and includes proliferation center, fishing, processing, sale and researching centers. Caviar industry is directly managed by government and the mother specialized agricultural company has responsibility for fishing, processing, sale and export of caviar. Having 40 Fishing centers, 30 processing centers, and 6 proliferation and release centers, This Company manages fishing and processing operation in Gillan, Mazandaran, and Golestan provinces. Now the government is trying to increase the participation of the private sector in the caviar industry and to attract foreign investment. Having Appropriate Depth and water temperature in Iran's coast, Iran has prominent position in fishing and farming sturgeon in a thousand kilometers of coastline of Caspian Sea. Iran's caviar industry is also benefiting from the expertise, professional workers, laboratories, research centers, and good technology, which create a competitive advantage in producing caviar for Iran. Iran also is known for having the best caviar in the world and has high strength in competitiveness.

The economic value of caviar has caused natural caviar producing countries try to create new markets and increase sales and lead fierce competition among them. Now the Iran, Russia, Kazakhstan, Azerbaijan and Turkmenistan are the world's producers of natural caviar. The competition between Iran and Russia for access to Europe and America markets is strong. High Quality of Iran caviar has led America, Germany, and UK to import largest amount of natural caviar from Iran and that Iran's competitors are trying to increase their share of the market in these countries. Reduced supply of natural caviar and its high price have caused increase of farmed caviar in the markets. Now Germany, America, France and China are the main producers of farmed caviar. Although farmed caviar as competitor of natural caviar causes Fluctuations In caviar markets, but Iran caviar preserves its position in global markets.

Another important point in the competitiveness is governments' role. Because governments' intervene in the political, economic and social affairs known as a major force influences industry in competitiveness. Economic relation, political agreements and cooperation between Caspian Sea basin countries are important factors than can help to improve industry of caviar.

\section{Research Background}

Shyam and his colleagues (2004) examined effect of globalization on export performance of Indian fisheries. The survey results show that globalization reduces the volatility and competitiveness of producers and exports of fishery products. The results also showed that microbial and bacterial contamination, and quality problems will reduce its exports

Kagawa and Bailey research (2006) studied the relationship between the importer companies of shrimp in Japan and its exporters in Thailand and Vietnam. The research results showed that the financial, technical, information and equipment assistance between the countries have many advantages for them and bring stability to the market, reduce sudden changes in market and increase quality and exports of products.

Boughanmi and his colleagues (2007) due to identify key variables affecting export performance and aim to Oman's fisheries export have done research in this country. The survey results showed that Recognition of market and cultures, customs and tastes of consumers is beneficial for exporters to utilize good situations. This study also showed that the product quality, product variety, the top management experience and familiarity with export procedures could improve the performance of export companies. 
In a study done by Husseini and his colleagues (2008), comparative advantage of Iranian caviar has been studied between 2000 and 2005 and export target markets of Iranian caviar have been prioritized by screening and numerical Taxonomy methods. The research results showed that in all these years Iran has comparative advantage in exports of caviar. Also the process of screening introduced Japan, South Korea, Oman, France, Norway and the numerical taxonomic process introduced Sweden, Germany, South Korea, England and Cyprus, as the best option to export caviar.

$\mathrm{Yu}$ and his colleagues (2008) examined shrimp exporters performance that exports to American market between 1991 and 2007. The survey results showed that during this period, competition among exporters has increased and small exporters increased their level of expertise and knowledge to enhance their competitiveness. These results also showed that exporters have changed their export Structure and focused on products that have a competitive advantage.

Allison and his colleagues (2009) examined the impact of climate change on national economy in fishing industry. The results showed that in countries where the fishing was main source of food, employment and exports, climate change might have a negative impact on their economies. Also, having more ability to adapt with climate change cause less negative influence their economies so they can have stronger economic.

Papavassiliou (2009) examined distribution system of fishery products in Greece in his research. The survey results showed that transportation and maintenance method was not suitable. High production costs, poor quality, inappropriate pricing and improper payments terms have reduced products sale. This survey also showed that marketing elements of distribution is effective in competitiveness and managements' Attitudes and companies' properties affect these marketing elements of companies.

Shinoj and his colleagues (2009) have examined fishery products exports in India. Their research results showed that health and quality regulations and technical barriers of trade have reduced the country's exports. The lack of adequate infrastructure and lack of processing, packaging and products grading equipments reduce production ability and cause difficulty for fishery products exports.

Marta and Ferre (2009) reviewed the effect of export-oriented aquaculture on development of developing countries in their research. The survey results showed that the aquaculture industry is a beneficial business and is useful for economy of countries. Aquaculture industry on one hand, increase exports and economic growth of countries and on the other hand, improve quality of people life by increasing the food safety of people.

\section{Methodology}

Because we try to resolve one practical problem in the real field, this research is an Applied Research. Also because research examines the characteristics of a population base on sampling of individuals and tries to Analysis and processing the data for the judge about population this research is a descriptive-cognition research. The survey information is collected from books and journals and assumptions checked base on data collected from a questionnaire. Questionnaire designed by researchers that have 25 questions with five selective choices, between the most and the least. The statistical sample of research includes fifty experts and exporters of caviar in companies' producer and exporter in Gillan and mazandaran province. Random sampling method was used and 90 questionnaires were distributed. SPSS software and One-sample t-test has been used for analyze data.

\section{Hypothesizes and Finding}

In this section we try to test hypothesizes by presumption statistics method ( $\mathrm{t}$ test). Results are shown in Table 1.

\subsection{First Hypothesis}

$\boldsymbol{H}_{1}$ : Familiarity of the Exporters with exports principles is effective on development of Iran's caviar exports.

As shown in Table 1, significant level (0.0007) is less than 0.01, so with the possibility of $99 \%$, the hypothesis is accepted. Using inefficient method of exports and lack of knowledge regarding modern methods cause reduction in share of Iran's caviar export market, therefore increase awareness and knowledge of Exporters about Advanced methods of receiving and payment of money, Customs regulations, shipping procedures, economic variables affecting on export and new rules and procedures in export and marketing Can help to increase exports of caviar. Training classes, Print books and Magazines in the field of export, employ of educated people in Export Corporation, hold seminars and conferences in the field of export, introduction successful corporation, and Cooperation of export corporations with universities and scientific organization helps to Familiarity of the Exporters with new knowledge and exports principles. 
Table 1. Results of T test

\begin{tabular}{lllll}
\hline variable & $\mathrm{T}$ & Min & Df & Sig \\
\hline Familiarity with exports principles & 1.892 & 3.25 & 50 & 0.0007 \\
Introducing nutritive and treatment value & 0.826 & 3.97 & 50 & 0.0004 \\
Foreign investment & 0.669 & 3.95 & 50 & 0.0051 \\
Diversification in the packaging capacity & 0.746 & 3.95 & 50 & 0.0002 \\
Proper processing and high quality & 0.005 & 3.35 & 50 & 0.0058 \\
good political relations & 2.525 & 3.61 & 50 & 0.0032 \\
Producing farmed caviar & 2.581 & 3.12 & 50 & 0.07 \\
\hline
\end{tabular}

\subsection{Second Hypothesis}

$\boldsymbol{H}_{2}$ : Introducing nutritive and treatment value of caviar to the goal markets is effective on development of Iran's caviar exports.

As shown in Table, Base on analysis of data, with the possibility of $99 \%$, this hypothesis is accepted (sign= $0.0004 \leq .01)$.

One of the most important factors that majority of the people are considering in food products is their nutritional and beneficial values for their health. Considering to the high nutritional and treatment value of caviar, Increase public awareness about the nutritional value and health benefits of that can be used to create tend to consume in people and increase sale, Also market's awareness from superior nutritional and health value of natural caviar compare to farmed caviar can help to strengthen the position of Iran in global markets. Producers and Exporters can Show benefits of caviar by publicity, Magazines and packs tag and increase public awareness.

\subsection{Third Hypothesis}

$\boldsymbol{H}_{3}$ : Foreign investment absorption is effective on development of Iran's caviar exports.

As shown in Table 1, significant level (0.0051) is less than 0.01 , so with the possibility of $99 \%$, this hypothesis is accepted.

Due to the special position of Iran's caviar production, foreign investors are interested to invest in this industry. Foreign investment is one of the best solutions for financing the projects related to the caviar industry and can helps regarding entering the new technology and science for increasing the fishes and production, Familiarity with foreign markets and expands exports. Therefore, protecting investors, Creating security and investment opportunities and conditions for foreign companies, can motivate them to increase investment in Iran.

\subsection{Fourth Hypothesis}

$\boldsymbol{H}_{4}$ : Diversification in the packaging capacity of caviar based on consumer's purchasing power is effective on development of Iran's caviar exports.

Because significant level (0.0002) is less than 0.01 , with the possibility of $99 \%$, this hypothesis will accept (Table, 1). One of the characteristic of Iranian caviar is the price of that, which is high. World economic crisis in recent years has reduced people's income and reduced buying caviar, therefore packed caviar in containers with high capacity caused the price of caviar high and only restaurants, hotels, wealthy people can afford to buy, so we lost many people of market who can be our customers and also like to eat this tonic food. As regards to this, that is impossible to consumed too much caviar in a meal because of high calorie and nutritional value and also cannot keep it for long time, so it seems the best way for increasing the sale and covering majority of market's people is to sale that also in multi-Grammy Pack. Packaging and export of caviar in small Pack restrain jobbery of some competitors. Export of caviar in big pack some competitors are encouraged to re-packaging of Iran's caviar and export that with own name.

\subsection{Fifth Hypothesis}

$\boldsymbol{H}_{5}$ : Proper processing and high quality of caviar is effective on development of Iran's caviar exports.

About the fifth hypotheses, as shown in Table 1, significant level $(0.0058)$ is less than 0.01 , so with the possibility of $99 \%$, the hypothesis is accepted. Quality is one of the most important factors in the purchase and exports of food products. Caviar production of high quality, so that the flavor, color, smell and shelf life be appropriate can make satisfy the consumers, Gain export health certificates, and increase exports. Using high quality raw materials, employing skilled personnel and appropriate processing methods can help improve the quality of the caviar production. 


\subsection{Sixth Hypothesis}

\section{$\boldsymbol{H}_{6}$ : Having good political relations with other countries is effective on development of Iran's caviar exports.}

Because significant level $(0.0032)$ is less than 0.01 , with the possibility of $99 \%$, this hypothesis will accept (Table, 1). Having good political relations with other countries at the international level is one of the most important factor for progress and economic growth in today's world, regarding this mater although Iran always trying to have good relation with other countries, around of the world but unfortunately still is under UN economic sanctions and many companies cannot establish trade relations with Iran, so we hope Iran's political authorities can solve this problem and make appropriate condition for the export of this especial product. Formal and informal Political agreements diplomats of Iran and collaboration with other country and international organization create Provides fertile ground for business, research and financial collaboration Iranian corporation with other country. Also being good political relations with other countries increase security investment in the Iran and cause to absorb of foreign investment.

\subsection{Seventh Hypothesis}

\section{$\boldsymbol{H}_{7}$ : Producing farmed caviar by other country has positive effect on development of Iran's caviar exports.}

Because significant level (0.07) is not less than 0.05 , with the possibility of $95 \%$, this hypothesis will rejected (Table, 1). In the past decade, several countries have turned to producing and exporting farmed caviars, among them some countries have been able to produce cheap caviar from ordinary fishes that are not inherently Sturgeon and Increase their share in the global market. At present, cheap prices of farmed caviar, Inability of consumers to recognize the natural caviar and unfamiliarity of them with the benefits of natural caviar are challenges facing natural caviar.

\section{Conclusion}

Caviar is one of the major export products of Iran and has Thriving market in developed country, Preliminary analysis showed that the export of Iranian caviar in the past decade have greatly reduced, in This study was an attempt to discovered factors that can increase exports of caviar and remained hidden from the view of those involved in this industry and then examined them, The results confirmed all of the hypothesis and showed, Diversification in the packaging capacity, good political relations, processing and quality of caviar, familiarity of the Exporters with exports principles, introducing nutritive and treatment value of caviar, and foreign investment absorption will increase the export but producing farmed caviar decrease export's volume. Base these result we can say that effort and close relation the government, producers and exporters together help to development of caviar exports. Government should facilitate export Laws, deducts as much as possible taxes, and give Donations to producers and exporters. Producer should use modern technology and methods in Fishing, farming and processing in order to increase the quality and health of products, reduce the final cost and produce according to customer's income, need and interest. In addition, exporters should try to find new knowledge and useful method in marketing and export. In this regard, other factors such as, Poor action of region's countries to combat smuggling and illegal fishing, construction of bridges and dams on the rivers near the spawning areas of Sturgeon and the Caspian Sea pollution are also reducing the sturgeon stocks. Cooperation of countries to remove above problems and protect the ecosystem of the Caspian Sea assists to increase Sturgeon population and fishing. Finally, producing farmed caviar from Sturgeon is a good solution for increase product of Iran's caviar and Reduce the threat Farmed caviar exports by other countries. enough resources and good condition for produce high quality farmed caviar, Name and reputation of Iran in produce caviar, new knowledge and technology in produce of hybrid sturgeon with Low maturity are strength point that Iran has them and their use can help Iran to produce high quality caviar with cast and time less than other country and Increase Iran's share in the global market.

\section{References}

Aghbaie, F., \& Falahati, A. A. (2008). Caviar fish and caviar. Journal of Agriculture science, 208, 30-31.

Aghdaie, S. F. (2009). Investigating effective factors on Iran's pistachio exportation. International journal of marketing studies, 1(2), 35-40.

Allison, E. H., Perry, A. L., Badjeck, M. C., Adger, W. N., Brown, K., Conway, D., . . Dulvy, N. K. (2009). Vulnerability of national economies to the impacts of climate change on fisheries. Fish and fishery, 10, 73-196. http://dx.doi.org/10.1111/j.1467-2979.2008.00310.x

Badiani, A., Anfossi, P., Fiorentini, L., Gatta, P. P., Manfredini, M., Nanni, N., . . . Tolomelli, B. (1996). Nutritional Composition of Cultured Sturgeon (Acipenserspp). Journal of Food Composition and Analysis, 
9(2), 171-190. http://dx.doi.org/10.1006/jfca.1996.0024

Birstein, V. J. (2002). Sturgeon Species and Hybrids: Can Hybrids Produce Caviar. Environmental policy and law, 32(5), 210-214.

Bledsoe, G. E., Bledsoe, C. D., \& Rasco, B. (2003). Caviars and Fish Roe Products. Critical Reviews in Food Science and Nutrition, 43, 317-356. http://dx.doi.org/10.1080/10408690390826545

Boughanmi, H., Al-Mandheri, A., Al-Oufi, H., \& Omezzine, A. (2007). Determinants of Fish Export Performance in Oman. Journal of International Food \& Agribusiness Marketing, 19(2), 9-25. http://dx.doi.org/10.1300/J047v19n02_02

Caprinoa, F., Moretti, V. M., Bellagambaa, F., Turchinib, G. M., Busetto, M. L., Giani, I., . . Pazzaglia, M. (2008). Fatty acid composition and volatile compounds of caviar from farmed white sturgeon (Acipenser transmontanus). Analytic chimica acta, 617(1-2), 139-147.

Carlos, M. P., Emilio, R., \& Fernando, L. (2010). The Key Role of Managers' Values in Exporting: Influence on Customer Responsiveness and Export Performance. Journal of International Marketing, 18, 1-19. http://dx.doi.org/10.1509/jimk.18.2.1

Chehabi, H. E. (2007). How Caviar Turned Out to Be Halal. Journal of food and culture, 7, 17-23.

Cho, D. S., \& Moon, H. C. (2000). From Adam Smith to Michael Porter. Singapore: World Scientific.

Cho, D. S., Moon, H. C., \& Kim, M. Y. (2008). Characterizing international competitiveness in international business research: A MASI approach to national competitiveness. Research in International Business and Finance, 22, 175-192. http://dx.doi.org/10.1016/j.ribaf.2007.04.002

Cho, D., Moonb, H., \& Kimc, M. (2008). Characterizing international competitiveness in international business research: A MASI approach to national competitiveness. Research in International Business and Finance, 22, 175-192. http://dx.doi.org/10.1016/j.ribaf.2007.04.002

Dashti, Gh., Khodavardizade, M., \& Mohammad, R. (2010). Analysis of comparative advantage and Structure of pistachio's export global market. Journal of Agricultural Economics and Development, 24, 99-106.

Ekaterina, S. (2005). The great Caspian caviar game. Security index, 13, 55-78.

Feurer, R., \& Chaharbaghi, K. (1998). Defining Competitiveness: A Holistic Approach. Management Decision, 32, 49-58. http://dx.doi.org/10.1108/00251749410054819

Francis, B., Iyare, S. O., \& Lorde, T. (2007). Agricultural export diversification and economic growth in Caribbean countries: Co integration and Error-Correction Models. The international trade journal, 32, 229-256. http://dx.doi.org/10.1080/08853900701416325

Gessner, J., Wirth, M., Kirschbaum, F., \& Patriche, N. (2002). Processing techniques for caviar and their effect on product composition. International Review of Hydrobiology, 87, 645-650. http://dx.doi.org/10.1002/1522-2632(200211)87:5/6<645::AID-IROH645>3.0.CO;2-K

Gessner, J., Wirth, M., Kirschbaum, F., Kru ger, A., \& Patriche, N. (2002). Caviar composition in wild and cultured sturgeons - impact of food sources on fatty acid composition and contaminant load. Journal of Applied Ichthyology, 18, 665-672. http://dx.doi.org/10.1046/j.1439-0426.2002.00366.x

Johannesson, J. (2006). Lumpfish caviar from vessel to consumer. FAO Fisheries Technical Paper, 485. Rome, FAO.

Joon, H. S., Alexandra, C. M., \& Barbara, A. R. (2010). Quality Attributes andMicrobial Storage Stability of Caviar from Cultivated White Sturgeon (Acipenser transmontanus). Journal of food science, 75(1), 43-48. http://dx.doi.org/10.1111/j.1750-3841.2009.01409.x

Julian, C., \& Yunus Ali, M. (2009). Incentives to export for Australian export market ventures. Journal of Small Business and Enterprise Development, 16, 418-431. http://dx.doi.org/10.1108/14626000910977143

Kagawa, M., \& Bailey, C. (2006). Trade Linkages in Shrimp Exports: Japan, Thailand and Vietnam. Development Policy Review, 24, 303-319. http://dx.doi.org/10.1111/j.1467-7679.2006.00326.x

Kantapipat, W. (2009). The Determinants of Successful Export Marketing Strategy in Thai Processed Agricultural Products. RU. International journal, 3, 91-102.

Kaushik, S. J., Luquet, P., Blanc, D., \& Paba, A. (2003). Studies on the nutrition of Siberian sturgeon, Acipenser baeri: I. Utilization of digestible carbohydrates by sturgeon. Aquaculture, 76, 97-107. 
http://dx.doi.org/10.1016/0044-8486(89)90254-8

Keyvanshokooh, S., \& Vaziri, B. (2008). Proteome analysis of Persian sturgeon (Acipenser persicus) ova. Animal Reproduction Science, 109, 287-297. http://dx.doi.org/10.1016/j.anireprosci.2007.10.008

Kohneshari, M., \& Nakami, Gh. (1996). Artificial reproduction and Breeding of sturgeons. Tehran: Institute of Publications and Printing of Tehran University.

Lau, C. K., To, K. M., Zhang, Z., \& Chen, J. (2009). Determinants of Competitiveness: Observations in China's Textile and Apparel Industries. China \& World Economy, 17, 45-64. http://dx.doi.org/10.1111/j.1749-124X.2009.01141.x

Marta, G., \& Ferre, R. (2009). Can Export-Oriented Aquaculture in Developing Countries be Sustainable and Promote Sustainable Development? The Shrimp Case. J Agric Environ Ethics, 22, 301-321. http://dx.doi.org/10.1007/s10806-009-9148-7

Meltzera, L., \& Chang, J. O. (2006). Export market influence on the development of the Pacific shrimp fishery of Sonora, Mexico. Ocean \& Coastal Management, 49, 222-235. http://dx.doi.org/10.1016/j.ocecoaman.2006.02.009

Mojaver, F. (2009). Sources of economic growth and stagnation in Iran. The Journal of International Trade \& Economic Development, 18, 275-295. http://dx.doi.org/10.1080/09638190902916519

Moradi, Y. (2003). HACCP in Iranian Caviar. Emir. J. Agric. Sci, 15, 72-79.

Murad, A., \& Rasco, B. A. (2005). Characterization of salmon and sturgeon caviar proteins. Journal of Food Biochemistry, 30, 422-428.

Papavassiliou, N. (2009). Fishery Products Distribution and Logistics in Greece. Journal of Food Products Marketing, 15, 38-63. http://dx.doi.org/10.1080/10454440802470581

Pikitch, E. K., Doukakis, P., Lauck, L., Chakrabarty, P., \& Erickson, D. L. (2005). Status, trends and management of sturgeon and paddlefish fisheries. Fish and Fisheries, 6, 233-265. http://dx.doi.org/10.1111/j.1467-2979.2005.00190.x

Porter, M. E. (1986). Competition in global industries: A conceptual framework. In M. E. Porter (Ed.), Competition in global industries. Boston, MA: Harvard Business School Press.

Porter, M. E. (1990). The competitive advantage of nations. New York: Free Press.

Porter, M. E., \& Armstrong, J. (1992). Canada at the crossroads: Dialogue. Business Quarterly, Spring, 6-10.

Porter, M. E., \& the Monitor Company. (1991). Canada at the crossroads: The reality of a new competitive environment. Business Council on National Issues and Minister of Supply and Services of the Government of Canada, Ottawa.

Raissa, P., Khodorevskaya, G. F., Dovgopol, O. L., \& Anatolii, D. V. (1997). Present status of commercial stocks of sturgeons in the Caspian Sea basin. Environmental Biology of Fishes, 48, 209-219. http://dx.doi.org/10.1023/A:1007381418332

Raymakers, C. (2002). International Trade in Sturgeon and Paddlefish Species - the Effect of CITES listing. $\begin{array}{lllll}\text { International Review } & \text { of } & \text { Hydrobiology, } & 87, & \text { 525-537. }\end{array}$ http://dx.doi.org/10.1002/1522-2632(200211)87:5/6<525::AID-IROH525>3.0.CO;2-W

Raymakers, C. (2006). CITES, the Convention on International Trade in Endangered Species of Wild Fauna and Flora: its role in the conservation of Acipenseriformes. Journal of Applied Ichthyology, 22, 53-65. http://dx.doi.org/10.1111/j.1439-0426.2007.00929.x

Rugman, A. M. (1991). Diamond in the rough. Bus, Q, 55(3), 61-64.

Rugman, A. M., \& D'Cruz, J. R. (1993). The double diamond model of international competitiveness: the Canadian experience. Management International Review, 33, 17-39.

Sagheer, S., Yadav, S. S., \& Deshmukh, S. G. (2007). Assessing International Success and National Competitive Environment of Shrimp Industries of India and Thailand with Porter's Diamond Model and Flexibility Theory. Global Journal of Flexible Systems Management, 8, 31-43.

Salmani, A., Safari, R., Soltani, M., \& Tavakoli, H. R. (2009). Growth and toxigenesis behavior of Clostridium botulinum type E in Persian sturgeon (Acipenser persicus) Caviar prepared with various preservatives. International Journal of Veterinary Research, 3, 17-23. 
Sanders, B. J., Fadel, J. G., \& Wade, E. M. (2003). Economic optimization modeling of white sturgeon caviar and meat production under different management conditions. Aquaculture, 217, 409-430. http://dx.doi.org/10.1016/S0044-8486(02)00577-X

Secor, D. H., Arefjev, V., Nikolaevm, A., \& Sharov, A. (2000). Restoration of sturgeons: lessons from the Caspian Sea Sturgeon Ranching Programme. Fish and Fisheries, 1, 215-230. http://dx.doi.org/10.1046/j.1467-2979.2000.00021.x

Shafaei, R. (2009). An analytical approach to assessing the competitiveness in the textile industry. Journal of Fashion Marketing and Management, 13, 20-36. http://dx.doi.org/10.1108/13612020910939851

Shinoj, P., Kumar, B. G., Joshi, P. K., \& Datta, K. K. (2009). Export of India's fish and fishery products: Analyzing the changing pattern / composition underlying causes. Indian Journal of Agricultural Economics, 64, 541-556.

Shyam, S. S., Sekhar, C., Uma, K., \& Rajesh, S. R. (2004). Export Performance of Indian Fisheries in the Context of Globalisation. Indian Journal of Agricultural Economics, 59, 448-464.

Singh, R. K., Garg, S. K., \& Deshmukh, S. G. (2007). Strategy development for competitiveness: a study on Indian auto component sector. International Journal of Productivity and Performance Management, 56, 285-304. http://dx.doi.org/10.1108/17410400710745315

Ural, T. (2007). The effects of relationship quality on export performance. European Journal of Marketing, 43, 139-168. http://dx.doi.org/10.1108/03090560910923274

Ustaoglu, S., \& Okumus, I. (2004). The Sturgeons: Fragile Species Need Conservation. Turkish Journal of Fisheries and Aquatic Sciences, 4, 49-57.

Vecsei, P. (2005). Gastronome 101: How capitalism killed the sturgeons. Environmental Biology of Fishes, 73, 111-116. http://dx.doi.org/10.1007/s10641-004-3152-6

Vosoghi, Kh., \& Behzadi, M. (1995). Freshwater fish. Tehran: Institute of Publications and Printing of Tehran University.

Walley, K. (1998). Competition: what does it really mean? The TQM Magazine, 10, 186-189. http://dx.doi.org/10.1108/09544789810214819

Wang, W., Batterman, S., Chernyak, S., \& Nriagu, J. (2008). Concentrations and risks of organic and metal contaminants in Eurasian caviar. Ecotoxicology and Environmental Safety, 71, 138-148. http://dx.doi.org/10.1016/j.ecoenv.2007.06.007

Williota, P., Sabeaub, L., Gessnerc, J., Arlatid, G., Bronzie, P., Gulyasf, T., \& Bernig, P. (2001). Sturgeon farming in Western Europe: recent developments and perspectives. Aquat. Living Resour., 14, 367-374.

Wirth, M., Kirschbaum, F., Gessner, J., Kruger, A., Patriche, N., \& Billard, R. (2000). Chemical and biochemical composition of caviar from different sturgeon species and origins. Nahrung, 44, 233-237. http://dx.doi.org/10.1002/1521-3803(20000701)44:4<233::AID-FOOD233>3.0.CO;2-1

Yu, R., Cai, J., \& Leung, P. S. (2008). An exploratory performance assessment of shrimp exporters for the U.S. $\begin{array}{lllll}\text { market. Aquaculture } \quad \text { Economics } \quad \text { \& } & \text { Management, } & 12, & \text { 225-25. }\end{array}$ http://dx.doi.org/10.1080/13657300802494115 